\title{
Treatment of Abdominal Pain in Cystic Fibrosis by Oral Administration of $\mathrm{n}$-Acetyl Cysteine
}

\author{
MICHAEL GRACEY, * VALERIE BURKE, and CHARLOTTE M. ANDERSON† \\ From the Gastroenterological Research Unit, Royal Children's Hospital Research Foundation, Royal Children's Hospital, \\ Melbourne, 3052, Victoria, Australia
}

Changes in the management of cystic fibrosis have resulted in more prolonged survival (Shwachman and Kulczycki, 1958; Gracey and Anderson, 1969) and have introduced new problems associated with the management of this group of patients.

In 1954, McIntosh described 23 patients with cystic fibrosis over 10 years of age with abdominal pain of undetermined cause, probably related to inspissated intestinal contents which can often be felt on abdominal examination. This may not be relieved by the 'usual' treatments with laxatives and enemas, and may be severe enough to require narcotics for relief. The importance of this symptom has only recently been widely recognized, and several reports have indicated the high mortality accompanying surgical treatment for this complication, when associated with intestinal obstruction. Various conservative measures, such as nasogastric lavage, or pancreatic enzyme, or n-acetyl cysteine enemas (Snyder et al., 1964) have been recommended, but their limited success has often led to operative intervention (Garnham and Carter, 1964; Hunton, Long, and Tsumagari, 1966).

The successful treatment by Lillibridge, Docter, and Eidelman (1967) of severe abdominal pain in an adult with cystic fibrosis with oral administration of n-acetyl cysteine (Mucomyst $\ddagger$ ) prompted us to attempt this form of treatment in our patients. We have now managed 5 patients in this way for periods of up to 6 months, with similar encouraging results.

\section{Material and Methods}

Six patients, aged from 5 to 19 years, with cystic fibrosis have been recommended to take n-acetyl cysteine since June 1968. These were all the patients

Received March 5, 1969.

^Supported by a Mead Johnson Research Fellowship. †Present address: Institute of Child Health Birmingham, 16. $¥$ Mucomyst-Mead Johnson. attending this clinic and complaining of abdominal pain. All patients were receiving our routine treatment with pancreatic extract ${ }^{\star}$ with meals, salt supplements, and intermittent aerosol therapy. The clinical status of patients was assessed by the method described by Shwachman and Kulczycki (1958).

n-acetyl cysteine $(20 \%)$ was diluted to twice its original volume with distilled water and given in a dosage of $5 \mathrm{ml}$. four times daily for 1 to 2 weeks, then $5 \mathrm{ml}$. three times daily for 1 to 2 weeks, then $5 \mathrm{ml}$. twice daily for 1 to 2 weeks, and finally $5 \mathrm{ml}$. daily or less frequently for maintenance. A flavoured liquid (usually a cola beverage) was used as a vehicle.

\section{Results}

The relevant clinical featurcs are shown in the Table.

One patient (Case 3) refused to take the medication and his episodes of abdominal pain continued unabated. In the other 5 patients abdominal pain ceased entirely within 1 week of starting $\mathbf{n}$-acetyl cysteine therapy.

The response was dramatic in Case 1 , whose pain had been severe enough to require the frequent administration of narcotics in the preceding 2 years. Because of the unusual severity of the symptoms, extensive investigation was undertaken at another hospital and included cholecystogram, liver function tests, barium studies, and pancreatic function tests. The cause of her pain remained unsolved, and laparotomy was contemplated. n-acetyl cysteine treatment was started, and her remarkable and timely response avoided surgical intervention.

Two patients had faecal masses palpable in the right iliac fossa at the start of treatment. The masses had disappeared when the patients were next examined, 2 weeks and 4 weeks respectively after starting treatment.

No side effects resulting from this treatment have been noticed.

\footnotetext{
*Viokase-Viobin Corporation.
} 
TABLE

\section{Results of Treatment of Abdominal Pain in Six Patients with Cystic Fibrosis by Oral Administration of} n-Acetyl Cysteine

\begin{tabular}{|c|c|c|c|c|c|c|c|c|}
\hline $\begin{array}{l}\text { Case } \\
\text { No. }\end{array}$ & Sex & $\begin{array}{c}\text { Age at } \\
\text { Diagnosis } \\
\text { (yr. })\end{array}$ & $\begin{array}{l}\text { Current } \\
\text { Clinical } \\
\text { Status }\end{array}$ & $\begin{array}{l}\text { Age at } \\
\text { Onset of } \\
\text { Abdominal } \\
\text { Pain (yr.) }\end{array}$ & $\begin{array}{l}\text { Abdominal Mass } \\
\text { Palpated before } \\
\text { n-Acetyl Cysteine } \\
\text { Treatment }\end{array}$ & $\begin{array}{c}\text { Age at Start } \\
\text { of n-Acetyl Cys- } \\
\text { teine Treatment } \\
\text { (yr.) }\end{array}$ & $\begin{array}{c}\text { Duration of } \\
\text { n-Acetyl Cysteine } \\
\text { Treatment } \\
\text { (mth.) }\end{array}$ & Results \\
\hline $\begin{array}{l}1 \\
2\end{array}$ & $\begin{array}{l}\text { F } \\
\text { F }\end{array}$ & $\begin{array}{c}7 \\
4 / 12\end{array}$ & $\begin{array}{l}\text { Good } \\
\text { Good }\end{array}$ & $\begin{array}{r}18 \\
7\end{array}$ & $\begin{array}{l}\text { No } \\
\text { Yes }\end{array}$ & $\begin{array}{r}2.1 \\
9\end{array}$ & $\begin{array}{l}6 \\
3\end{array}$ & $\begin{array}{l}\text { No further pain } \\
\text { No further pain; } \\
\text { abdominal mass } \\
\text { impalpable after } 1 \mathrm{mth} \text {. } \\
\text { treatment }\end{array}$ \\
\hline 3 & $\mathbf{M}$ & $6 / 12$ & Excellent & 5 & No & 8 & Nil & $\begin{array}{l}\text { Refused to take treat- } \\
\text { ment: pain continues } \\
\text { unabated }\end{array}$ \\
\hline 4 & F & 4 & Good & 13 & Yes & 13 & 4 & $\begin{array}{l}\text { No further pain; } \\
\text { abdoninal mass } \\
\text { impalpable after } 2 \text { wk. } \\
\text { treatment }\end{array}$ \\
\hline 5 & $\mathbf{F}$ & $2 / 12$ & Excellent & 5 & No & 5 & 3 & No further pain \\
\hline 6 & $\mathbf{F}$ & $10 / 12$ & Good & 7 & No & 9 & 3 & No further pain \\
\hline
\end{tabular}

^From Shwachman and Kulczycki (1958).

\section{Discussion}

Our experience confirms the therapeutic benefit of $n$-acetyl cysteine given orally for the relief of the abdominal pain which occurs not uncommonly in patients with cystic fibrosis, and which is probably related to inspissated intestinal contents which can often be felt on abdominal examination.

In all 5 patients relief occurred within a week of starting this treatment, and in one it was dramatic.

No side effects were seen in this small group of patients over this brief period of time nor after a year of treatment in the one adult patient of Lillibridge et al. (1967).

Though n-acetyl cysteine has an unpleasant taste and odour, 5 of our 6 patients continued to take it because of their symptomatic improvement. The other patient refused to take the medication and his abdominal pains have continued during the 4 months since this treatment was first recommended.

The dosage we have used has been arbitrarily contrived and is considerably less than used by Lillibridge et al. (1967). In view of the offensive taste and high cost of n-acetyl cysteine it is desirable to attempt control of symptoms using a smaller maintenance dosage. Further experience with these patients will determine the optimal dosage and allow better evaluation of this treatment. Though our experience with oral $n$-acetyl cysteine is limited, we consider it to be valuable in managing recurrent abdominal pain in patients with cystic fibrosis.

\section{Summary}

Six patients with cystic fibrosis, aged from 5 to 19 years, have been recommended to take n-acetyl cysteine orally for relief of abdominal pain. One patient refused to take the medication; in the other 5 abdominal pain was relieved entirely within 1 week. Two patients had palpable abdominal masses which could no longer be felt soon after starting treatment.

We thank Dr. David Fone for allowing us to publish details of Case 1 .

\section{REFERENCES}

Garnhain, J. R., and Carter, T. R. G. (1964). Mechanical intestinal obstruction in a young adult male with mucoviscidosis. Gut, $5,2 j 6$.

Gracey, M., and Anderson, C. M. (1969). Cystic fibrosis of the pancreas in adolescence and adulthood. Aust. Ann. Med. April, 1969 (in the press).

Hunton, D. B., Long, W. K., and Tsumagari, H. Y. (1966). Meconium ileus equivalent: an adult complication of fibrocystic disease. Gastroenterology, 50, 99.

Lillibridge, C. B., Docter J. M., and Eidelman, S. (1967). Oral administration of n-acetyl-cysteine in the prophylaxis of 'meconium ileus equivalent'. F. Pediat., 71, 887.

McIntosh, R. (1954). Cystic fibrosis of the pancreas in patients over ten years of age. Acta paediat. (IJppsala), 43, Suppl. 100, 469.

Shwachman, H., and Kulczycki, L. L. (1958). Long-term study of one hundred five patients with cystic fibrosis. Studies made over a five- to fourteen-year period. Amer. $\mathcal{F}$. Dis. Child., 96, 6.

Snyder, W. H., Jr., Gwinn, J. L., L.anding, B. H., and Asay, L. D. (1964). Fecal retention in children with cystic fibrosis. Report of three cases. Pediatrics, 34, 72.

Correspondence to Professor Charlotte M. Anderson, The Institute of Child Health, The Nuffield Building, Francis Road, Birmingham 16. 